\title{
Zarys DZIEJów Filmoteki NARODOWEJ
}

http://dx.doi.org/10.12775/AKZ.2014.003

Słow a kluczowe: Filmoteka Narodowa; gromadzenie filmów; film; archiwum filmowe; dokumentacja audiowizualna; dokumentacja specjalna

Ke y word s: National Film Archives; collecting films; film; film archive; audiovisual records; special records

Streszczenie

Artykuł przedstawia zarys historii najstarszej w Polsce instytucji gromadzącej filmy. Filmoteka Narodowa rozpoczęła swoją działalność w latach 50. ubiegłego wieku i od tamtej pory jest instytucją w Polsce posiadającą największy zasób filmów, w szczególności fabularnych. Dzieje tej instytucji po części pokazują również historię kinematografii polskiej. Zasób filmów jest dorobkiem naszej kultury narodowej. W artykule przedstawione są dzieje tejże instytucji, która z państwowej firmy stała się jedną z bardziej komercyjnych i dochodowych gałęzi przemysłu. Zakres działalności Filmoteki Narodowej w Warszawie, od momentu jej utworzenia, nie uległ zasadniczej zmianie. Nadal jest to instytucja o charakterze centralnym, gromadząca i udostępniająca przede wszystkim filmy, ale także dokumentację filmową, druki efemeryczne związane z kinematografią oraz dokumentację fotograficzną dotyczącą historii kina polskiego. 
Wzorem krajów zachodnich, w Polsce już po II wojnie światowej, nastąpiły przesłanki do powołania archiwum filmowego, tym bardziej iż wtedy zaczęły pojawiać się organizacje międzynarodowe, które stowarzyszały takie archiwa, a w Polsce idea gromadzenia filmów narodziła się już w latach 20. XX w. ${ }^{1}$

Pierwsze archiwa filmowe zaczęły pojawiać się w Europie w 1935 r. w Londynie, później w Stanach Zjednoczonych w Nowym Jorku, a w 1938 r. w Paryżu i Berlinie ${ }^{2}$. Z ich inicjatywy w 1938 r. została powołana Międzynarodowa Federacja Archiwów Filmowych - FIAF (Fédération Internationale des Archive du Film) z siedzibą w Paryżu ${ }^{3}$. Organizacja dążyła przede wszystkim do swobodnej wymiany filmów dla celów kulturalnych, naukowych i oświatowych. Jednym ze statutowych haseł FIAF było: „Ani jedna taśma filmowa nie może ulec zniszczeniu"

Idea zachowania filmów z okresu przedwojennego, przynajmniej tej części, która nie została rozkradziona lub zniszczona, zaczęła kiełkować również w naszym kraju, gdzie w dziedzinie kinematografii, a szczególnie jeżeli chodzi o historię filmu, odczuwano duże braki. Żywo zaczęto interesować się historią filmu, a co za tym idzie chciano ocalić zbiory, które jeszcze się zachowały 5 .

Powołanie archiwum filmowego w Polsce trwało ponad 10 lat. Formalne utworzenie Archiwum Filmowego, jako instytucji gromadzącej filmy, nastąpiło w 1955 r. ${ }^{6}$ Jego zalążek powstał w latach 1945-1946, w krakowskiej Wytwórni Filmowej. Funkcjonowało to ówcześnie jako zbiór filmów wykorzystywanych przy szkoleniu młodych kadr kinematografii w tzw. Warsztacie Filmów Młodych i na Kursie Przysposobienia Filmowego w Krakowie. Zbiory krakowskie i zbiory przedsiębiorstwa „Film Polski” przekazano Wyższej Państwowej Szkole Filmowej w Łodzi, przy której powstało pierwsze archiwum filmowe. Już znacznie wcześniej ukształtował się filar instytucji, której

1 Zobacz: M. Niedźwiedzka, Historia gromadzenia filmów w Polsce, „Archiwista Polski” 2014, nr 3, s. 41-55.

2 H. Robótka, Metodyka archiwalna. Opracowanie dokumentacji geodezyjno-kartograficznej, technicznej, audiowizualnej (fotografie, filmy, nagrania), Toruń 1988, s. 103.

3 E. Modrzejewska, Taśmy prawdy, „Film” 2005, nr 3.

4 R. Nowicki, Międzynarodowy Kongres archiwów Filmowych w Warszawie, „Archeion" 1956, t. 26.

5 M. Niedźwiedzka, dz. cyt., s. 42.

6 Uchwała $\mathrm{Nr}$ 330/55 Prezydium Rządu z dnia 29 kwietnia 1955 roku w sprawie utworzenia Archiwum Filmowego w Warszawie, http://www.fn.org.pl/page/file. php?id=1425 [dostęp: 28 XI 2014 r.] 
funkcjonowanie w decydujący sposób warunkuje stan kultury filmowej w naszym kraju ${ }^{7}$.

Wkrótce po tym, jak zaczęto gromadzić zasób filmowy, za sprawą profesora Jerzego Teoplitza w 1948 r., zgłoszono akces do Międzynarodowej Federacji Archiwów Filmowych FIAF, wprowadzając tym Polskę do grona najstarszych członków tej organizacji ${ }^{8}$. Niewielka organizacja powstała w Łodzi, startowała z zasobem 3000 filmów, dołączając do wymienionej organizacji międzynarodowej, przejęła jej założenia, które miały na celu przede wszystkim ochronę europejskiego dziedzictwa sztuki filmowej'. W ten sposób uformowano podstawy istnienia instytucji, która mogłaby zająć się w Polsce gromadzeniem filmów. Placówka powołana przy WPSF w Łodzi pełniła funkcje archiwum filmowego przez blisko 10 lat. Nie obejmowała ona zasięgiem całego kraju, nie została również powołana przez ówczesny rząd, to jednak jej istnienie spowodowało, że już wtedy gromadzenie filmów w Polsce miało charakter międzynarodowy, mimo iż nie posiadaliśmy placówki o takim samym statusie, co inni członkowie FIAF.

Dziesięć lat po rozpoczęciu działań, związanych z gromadzeniem dokumentacji filmowej, 29 kwietnia 1955 r., na mocy uchwały Prezydium Rządu, zostało powołane Archiwum Filmowe z siedzibą w Warszawie ${ }^{10}$. Była to pierwsza tego typu instytucja o charakterze centralnym, nastawiona przede wszystkim na gromadzenie wytworów kinematografii oraz wszystkiego, co z nią związane, fakt był ważnym momentem w historii gromadzenia filmów w Polsce. Upoważnionym organem założycielskim został Prezes Urzędu Kinematografii. Zakres działalności Archiwum Filmowego określono w dekrecie, w dziewięciu punktach. Miało ono zajmować się przede wszystkim archiwizacją i wystawiennictwem eksponatów dotyczących kinematografii ${ }^{11}$. Tym samym chciano stworzyć namiastkę muzeum kinematografii na wzór zachodnich instytucji. Ponadto placówka ta miała zając się prowadzeniem archiwum wszelkich filmów produkcji krajowej i zagranicznej, a także wszelkich dokumentów życia społecznego ich dotyczących oraz fotosów. Do tego archiwum miało prowadzić także centralny katalog dzieł filmowych ${ }^{12}$. Nie określono

${ }^{7}$ H. Tronowicz, Postannictwo i budżet, „Kino” 1985, nr 2.

${ }^{8}$ A. Zwaniecki, Notatka z okazji jubileuszu, „Tygodnik Kulturalny” 1980, nr 26.

9 R. Nowicki, dz. cyt., s. 261.

10 Uchwała Nr 330/55 Prezydium Rządu z dnia 29 kwietnia 1955 roku.

11 Tamże, $\$ 1$ i $\$ 2$ pkt 1.

12 Tamże, $\$ 2$ pkt 4 i 5 . 
jednak konkretnie, czy miałby to być katalog już zarchiwizowanych dzieł, czy też bieżącej produkcji. Nie ustalono niestety, na jakich zasadach miałoby odbywać się gromadzenie przede wszystkim ówcześnie powstających filmów. Zaczęły pojawiać się głosy za nadaniem archiwum egzemplarza obowiązkowego od producentów filmowych, na takiej zasadzie jak do Biblioteki Narodowej dostarczane są książki. Jako że Polska już od lat była członkiem FIAF, dużo w określaniu działalności Archiwum uwagi poświęcono prowadzeniu zagranicznej międzyarchiwalnej wymiany filmowej oraz utrzymaniu łączności z odpowiednimi instytucjami i organizacjami zagranicznymi ${ }^{13}$. Celem utrzymania tych kontaktów, była przede wszystkim rekonstrukcja zasobu filmów polskich z okresu kina niemego. Archiwum filmowe ponadto w zakresie swojej działalności miało prowadzenie prac naukowo-badawczych, a także prowadzenie akcji społeczno-oświatowych oraz wydawanie biuletynu z zakresu tejże działalności ${ }^{14}$. Utrzymanie Archiwum Filmowego mieściło się w budżecie państwa. Nie była to jednak samodzielna jednostka, która otrzymywała bezpośrednio pieniądze na swoją działalność. Jako że została utworzona pod Centralnym Urzędem Kinematografii, jej płynność finansowa również od niego była uzależniona ${ }^{15}$. Dlatego też w tym pierwszym okresie działalność instytucji była mocno ograniczona.

Biuro Archiwum Filmowego rozpoczęło działalność 15 czerwca 1955 r. w jednym małym wynajętym pokoiku przy ul. Puławskiej $61 \mathrm{w}$ Warszawie. Tam urzędowało trzech pracowników: Władysław Banaszkiewicz, bibliotekarz archiwista, Leon Birn, działacz klubów filmowych, miłośnik filmu, i Bolesław Michałek - krytyk, historyk kina. Przy ul. Długiej w Instytucie Sztuki PAN urzędował prof. Jerzy Teoplitz - projektodawca, inicjator i przewodniczący Rady Archiwum. Tak zaczęło się przejmowanie filmów ze Szkoły Łódzkiej, z Centrali Wynajmu Filmów i innych źródeł. Zaczęły się pierwsze próby porządkowania, katalogowania rejestrowania i konserwacji. Na początku starano się to robić przy pomocy angielskiej „Instrukcji katalogowania filmów”. Okazała się ona nie do przeskoczenia przez ówczesnych pracowników, była bardzo skomplikowana, drobiazgowa. Opisanie w ten sposób choćby jednego filmu w tamtych czasach i warunkach, przy tak niewielkiej liczbie

13 Tamże, $\$ 2$ pkt 6 i 7 .

14 Tamże, $\$ 2$ pkt 3, 8 i 9 .

15 Tamże, $\$ 3$. 
pracowników zajęłoby tygodnie, a może i miesiące ${ }^{16}$. Pierwszym dyrektorem nowo powołanej placówki został Władysław Banaszkiewicz, który piastował swój urząd przez następne 14 lat ${ }^{17}$.

W pierwszym pionierskim okresie działania instytucji wykrystalizowały się zasady i formy działania, które z pewnymi modyfikacjami przetrwały długie lata. W tym czasie zgromadzono podstawowe elementy zbioru filmowego $\mathrm{z}$ dawnego łódzkiego archiwum oraz w drodze wymiany, przede wszystkim zagranicznej $^{18}$. Pomimo tak rozbudowanych w uchwale przedmiotów działania Archiwum Filmowego, na samym początku jego działalności skupiono się przede wszystkim na rekonstrukcji i odzyskaniu utraconych zbiorów, o gromadzeniu bieżących produkcji polskich nie było jeszcze mowy. W miarę upływu lat, ta luka, która wytworzyła się właśnie w tym okresie, dała się we znaki. Niestety w dalszym ciągu nikt nie myślał o tym, aby główne archiwum gromadzące dzieła kinematografii mogło mieć coś takiego jak egzemplarz obowiązkowy produkcji polskich.

Jeszcze w tym samym roku w czerwcu, również w Warszawie, miał miejsce kongres Międzynarodowej Federacji Archiwów Filmowych (FIAF), której Jerzy Teoplitz był wieloletnim przewodniczącym. Zjawili się wtedy w stolicy wszyscy prominenci filmotek świata: Ernest Lindgren z Londynu, Lau Laritzen ze Sztokholmu, który swoje prywatne zbiory przekształcił w narodową filmotekę szwedzką, Jaques Ledoux dyrektor Królewskiej Filmoteki Belgijskiej oraz legendarny Henri Langlois, założyciel Cinémathèque Française, ojciec duchowy filmowców francuskich. To wydarzenie postawiło Archiwum Filmowe na równi z instytucjami w Europie, a przede wszystkim podniosło jego rangę na arenie międzynarodowej ${ }^{19}$.

Archiwum Filmowe nigdy nie chciało pozostać tylko instytucją, która zbiera, opracowuje i konserwuje swoje zbiory. Wydaje się, że dość istotną sprawą, na jaką zwrócono uwagę w tej jednostce, była chęć krzewienia kultury filmowej wśród społeczeństwa oraz obowiązek udostępniania swoich zbiorów, które miały się do tego przyczynić. Przede wszystkim chciano zacząć udostępniać zbiory audiowizualne na szerszą skalę i nie tylko w celach naukowo-badawczych, ale również w taki sposób, by uwrażliwić społeczność na sztukę

16 B. Michałek, Duch filmoteczny, „Kino” 1980, nr 6.

17 A. Bukowiecki, 55 lat Archiwum Filmowego, Jubileusz Filmoteki Narodowej, „Magazyn Filmowy" 2010, nr 13.

18 W. Piątek, 30 lat Filmoteki Polskiej, „Filmowy Serwis Prasowy” 1985, nr 11-12.

19 Tamże. 
filmową. Nie można było zrobić tego inaczej niż w kinie. Tak też w 1959 r. powstało pod egidą Archiwum Filmowego kino Iluzjon. Było to jedyne tego typu kino w Polsce udostępniające widzom dorobek rodzimej kultury i kinematografii ${ }^{20}$. Ciekawostką jest pochodzenie nazwy kina, otóż wywodzi się ono jeszcze z początków kinematografii w Polsce. Pierwsze kina na początku stulecia nazywano „iluzjonami”. W 1913 r. w warszawskim tygodniku „Świat” ukazał się wierszyk pt. Iluzjon, którego końcowa strofka w szczególny sposób obrazuje potrzebę społeczną gromadzenia i upowszechniania filmów, a brzmi ona tak: „lecz nie dziw, że gród syreni / iluzjonem zachwycony / kto jak my iluzje ceni/ musi cenić iluzjony"21.

W 1961 r. zarządzeniem Ministra Kultury i Sztuki wprowadzono nazwę Centralne Archiwum Filmowe ${ }^{22}$. Profil działalności instytucji nie uległ zmianie. Tym wydarzeniem chciano przede wszystkim podnieść rangę placówki, która od tej pory również tytularnie obejmowała zasięgiem całą Rzeczpospolitą.

W prasie końca lat 60. znaleźć można krótką wzmiankę o przykrym zdarzeniu, jakie miało miejsce 23 września 1967 r. Właśnie tego dnia, w jednym z pomieszczeń bibliotecznych Centralnego Archiwum Filmowego wybuchł pożar, podczas którego została zniszczona część zbiorów piśmiennictwa filmowego ${ }^{23}$. Nie określono natomiast, jak duże były to straty, niemniej z faktu, że cała zaistniała sytuacja nie została bardzo mocno nagłośniona, można wnioskować, iż w pożarze zniszczono tylko niewielką część zasobu książek o tematyce filmowej.

Takie były początki pierwszego w Polsce i jednego z pierwszych w Europie archiwum filmowego. Przez następne kilka lat głównie starano się odzyskać utracone zbiory, a także skatalogować te, które zostały już zgromadzone. Trudności było wiele - od problemów finansowych, kadrowych, po lokalowe. Niemniej te zadania, które zostały podjęte na samym początku, za kadencji dyrektora Władysława Banaszkiewicza, były skrupulatnie realizowane. To, co dało się znacząco odczuć w pracach archiwum, to brak działalności naukowo-

20 I. Cegiełkówna, Takie kino - rozmowa z Grażyną Grabowska, kierownikiem programowym Iluzjonu, „Reżyser” 2000, nr 3.

21 S. Beylin, Filmoteka Polska - Muzeum Sztuki Filmowej, „Stolica” 1980, nr 22.

22 O Filmotece Narodowej, http://www.fn.org.pl/page/index.php?str=669 [dostęp: 28 XI 2014 r.]

23 Pożar w archiwum, „Film” 1967, nr 42. 
-badawczej sensu stricto. $\mathrm{Na}$ europejskim poziomie została natomiast uplasowana działalność kulturalno-oświatowa.

W końcu lat 60 . fotel dyrektora objął Kazimierz Michalewicz ${ }^{24}$. Nowa osoba na tym stanowisku nie zmieniła diametralnie profilu działalności Centralnego Archiwum Filmowego. Starano się kontynuować rozpoczęte działania, ulepszać to, co zostało już wdrożone.

Niedługo nacieszono się nową nazwą instytucji. W 1970 r., na wzór zachodnich archiwów filmowych, nasza rodzima po raz kolejny zmieniła swoją nazwę. Centralne Archiwum Filmowe stało się Filmoteką Polską ${ }^{25}$. Pierwszym przyczynkiem do zmiany nazewnictwa była chęć nadania instytucji europejskiego charakteru, takiej jaką posiadało Cinémàtique Française w Paryżu. Ponadto instytucja powołana w Polsce nigdy nie chciała być postrzegano jako martwa, a w ten sposób patrzono na archiwa. Zmiana nazwy na Filmotekę Polską nie przeobraziła dotychczasowej działalności, a jedynie wpłynęła na wizerunek w społeczeństwie, gdzie zaczęto postrzegać ją nie tylko od strony gromadzenia filmów, ale i ich udostępniania. Znaczący wpływ na to miało oczywiści kino Iluzjon działające przy Filmotece, niemniej jak na tamten czas była to instytucja, która bardzo chciała wyjść naprzeciw użytkownikowi. Jako nadrzędną ideę postawiono sobie chęć uwrażliwiania społeczeństwa na sztukę filmową. W doskonały sposób ujął to w swoich słowach Henri Langlois, założyciel pierwszego archiwum filmowego w Paryżu, który powiedział: „Tragedią wszystkich Filmotek jest konieczność lawirowania pomiędzy upodobaniami publiczności a potrzebą kształtowania tych upodobań"26.

Do połowy lat 70. nie było nikogo, kto byłby dyrektorem tak długo jak założyciel i pierwszy dyrektor Władysław Banaszkiewicz. Jego następca wytrwał na tym stanowisku cztery lata. Po jego kadencji funkcję tę objął Henryk Mocek. Niestety on również nie nacieszył się nią długo. Od 1973 r. przez dwa lata dyrektorem był Jan Zbigniew Pastuszko. Dopiero w 1975 r długoletnią służbę podjął Roman Witek ${ }^{27}$. Ciągłe zmiany na stanowisku dyrektora nie dały możliwości wypracowania jakiegoś długoterminowego planu działania, dlatego też w tym czasie nie nastąpiły rewolucyjne zmiany w profilu działal-

\footnotetext{
24 B. Michałek, dz. cyt.

25 O Filmotece Narodowej.

26 H. Tronowicz, dz. cyt.

27 A. Bukowiecki, dz. cyt.
} 
ności instytucji. Dalej walcząc z problemami finansowymi, starano się uratować najcenniejsze i najstarsze zbiory.

W tym właśnie czasie, na łamach prasy czy też w wywiadach radiowych, rozmowach prywatnych i oficjalnych pracowników i użytkowników, zaczęto podkreślać brak możliwości prawidłowego działania Filmoteki. Przyczyny tego zjawiska nie leżały po stronie instytucji, wynikały one przede wszystkim z niewłaściwego jej finansowania. Ponadto Filmoteka nigdy nie posiadała pomieszczeń, ani laboratoryjnych do konserwacji dzieł filmowych, ani magazynowych, odpowiednich do przechowywania filmów. Do tego dochodziły jeszcze niewłaściwe unormowania prawne, które nadawały jej status instytucji kulturalno-oświatowej, a nie naukowej, co pozwalałoby zająć się konserwacją czy opracowywaniem zgromadzonego zasobu. Dlatego od momentu powołania instytucji ratowano i odzyskiwano zasób polskich filmów przedwojennych. W 1975 r. Filmoteka Polska była jedną z bodaj 40 działających na świecie, która nie zbierała bieżącej narodowej produkcji. Jej polskie zbiory zatrzymały się na 1939 r. Wprawdzie wydane w lutym 1957 r. rozporządzenie Rady Ministrów zaliczyło do zasobu archiwalnego również filmy, fotografie i nagrania dźwiękowe, ale nie zostało ono rozwinięte i poparte przepisami szczegółowymi, które określiłyby kto, co i na jakich zasadach zabezpiecza. W obliczu więc poplątania kompetencji i luk legislacyjnych dotyczących niektórych zagadnień, materiały filmowe przechowuje się na podstawie przepisów Naczelnego Zarządu Kinematografii, Naczelnej Dyrekcji Archiwów Państwowych, a także wewnętrznych zarządzeń poszczególnych instytucji, do których zaliczano Filmotekę, oraz ogólnych ustaleń finansowo-księgowych. Wśród nich nie znalazł się jednak żaden, który nakazywałby wytwórniom przekazywanie Filmotece kopii wzorcowej każdego wyprodukowanego filmu. W początkach 1974 r. rozpoczęły się rozmowy pomiędzy Naczelną Dyrekcją Archiwów Państwowych a Naczelnym Zarządem Kinematografii. Powołano wówczas komisję mieszaną, której zadaniem miało być ustalenie w tym ogólnym chaosie podziału kompetencji, wypracowanie form i zakresu gromadzenia, ujednolicenie przepisów archiwizacji, doprowadzenie do powstania wspólnej ewidencji. Okazało się jednak, że jest tyle problemów, iż komisja ugięła się pod ich ciężarem i po dwóch posiedzeniach zarzucono całą sprawę ${ }^{28}$.

W miarę upływu lat, a przede wszystkim rozwoju kinematografii polskiej, ustawowe rozwiązanie gromadzenia przez Filmotekę Polską produkcji filmo-

${ }_{28}$ M. Niezabitowska, Święty negatyw, „Kultura” 1975, nr 32. 
wej bieżącej wydawało się coraz pilniejsze. Filmoteka nie posiadała wszystkich kopii filmów fabularnych powstałych po wojnie, nie miała obowiązku ich gromadzenia, a i twórcy nie byli skorzy do ich przekazywania. Pracownicy instytucji, co prawda na własną rękę, próbowali zdobywać wszelką dokumentację dotyczącą polskich produkcji filmowych, a także kopii filmów. Niemniej jednak ich starania przez lata bardziej przypominały partyzantkę aniżeli świadome gromadzenie historii filmu i kina. W ten sposób Filmoteka Polska do 1980 r. miała 85\% polskich filmów fabularnych wyprodukowanych po wojnie. Dopiero wtedy uzyskała prawo tzw. kopii obowiązkowej na podobieństwo Biblioteki Narodowej. Dodajmy, że negatywy filmów, a więc podstawowy materiał wymagający ochrony, był poza jej zasięgiem ${ }^{29}$. W ten sposób kopia każdego filmu wyprodukowanego w Polsce miała zasilić zasób Filmoteki. Ponadto dzięki usilnym staraniom do początku lat 80. odzyskano 129 przedwojennych filmów dźwiękowych i 22 nieme. Jest to dużo i mało za razem, ponieważ przed wojną wyprodukowano 394 filmy fabularne z tego 232 nieme i 141 dźwiękowych, a więc bezpowrotnemu zniszczeniu uległa spora cześć zasobu historyczno-dokumentalnego kina polskiego. Do jednego z największych osiągnięć Filmoteki należało w owym czasie przekopiowanie setek tysięcy metrów taśmy łatwopalnej typu nitro na niepalną ${ }^{30}$. Jest to duża zasługa w dziedzinie ochrony dóbr historyczno-kulturowych, dlatego że z przyczyn czysto technicznych, w przypadku kiedy żadna instytucja nie zajęłaby się tym, mogłoby doprowadzić to do bezpowrotnego zniszczenia dzieł filmowych.

W 1981 r. Filmoteka Polska rozpoczęła, własnym nakładem, cykliczną działalność wydawniczą, w postaci kwartalnika „Iluzjon”, który w ciągu kilku lat wyrobił sobie znaczącą renomę pośród czytelników ${ }^{31}$.

Jak wielkie były zasługi Filmoteki Polskiej w rozwoju historii i kultury kinematografii, świadczyć może nagroda, którą w 1984 r. przyznało jej czasopismo „Kino”32. Instytucja zyskiwała coraz większą renomę na polu krajowym oraz międzynarodowym.

W 1985 r. Filmoteka Polska obchodziła swój jubileusz, 30-lecie istnienia. Wedle swego powołania zobowiązana była do wykonywania zadań wciąż jeszcze rozumianych w sposób dość tradycyjny. Dążyła przede wszystkim do

\footnotetext{
29 B. Michałek, dz. cyt.

30 U. Białous, Kiedy Chaplin ptacze, „Polityka” 1980, nr 21.

31 A. Ledochowski, Biedni bogacze, „Film” 1985, nr 16.

32 Notatka, „Kino” 1985, nr 1.
} 
zwiększenia posiadanej kolekcji filmów, z pierwszeństwem dla starań o uzupełnienie brakujących dzieł polskich oraz dzieł zrealizowanych przez polskich autorów czy też z udziałem polskich aktorów. Jej priorytetowym zadaniem było powiększać w miarę możliwości zasoby klasyki filmowej oraz wybitnych dzieł kina światowego. Rzecz jasna, równoczesnym pierwszoplanowym obowiązkiem tej instytucji było sporządzanie dokumentacji posiadanych zbiorów, wykonywanie prac filmograficznych, a także konserwatorskich oraz laboratoryjnych. Były to elementarne zadania archiwum filmowego. Pomimo dalszego funkcjonowania kina „Iluzjon”, które wbrew problemom lokalowym, nie traciło swoich stałych fanów, można odnieść wrażenie, iż udostępnianie filmów w celach oświatowych przez Filmotekę Polską zeszło na dalszy plan. Kustosz Filmoteki Polskiej, mówiąc wówczas o przedmiocie działalności archiwów filmowych, dopiero w tle zauważał udostępnianie zbiorów. Tym bowiem funkcjom przyznano w filmotecznej praktyce znaczenie niejako drugorzędne. Wynikało to z przekonania, iż archiwiści troszczyć muszą się przede wszystkim o zapewnienie ocalałym taśmom należytej ochrony. Zwróćmy uwagę na to, co w rozumieniu ówczesnego pracownika zalicza się do głównej działalności, a co występuje dopiero obok niej. Obok głównej działalności archiwa filmowe w coraz szerszym stopniu stawały się placówkami muzealnymi, prowadzącymi działalność naukową i inicjującymi studia nad przeszłością kinematografii, a także placówkami oświatowymi, udostępniającymi swoje zbiory, aby spopularyzować arcydzieła filmu. Nawet działalność o charakterze naukowym znalazła się w owej hierarchii zadań poza zakresem dawnych obowiązków. Postępowanie archiwistów było wówczas racjonalnie uwarunkowane i słusznie za swoją największą powinność uważali oni troskę o należyte zabezpieczanie narażonej na niszczenie substancji starych filmów. Gdyby eksploatacja była priorytetem, długo nie cieszylibyśmy się zasobem filmowym, szczególnie tym sprzed wojeny, który i tak po drugich bataliach udało się częściowo zrekonstruować. Warunki ekonomiczne, techniczne i lokalowe, w jakich prowadziła swoje prace Filmoteka, nie dawały praktycznie żadnej możliwości przyspieszenia prowadzonych prac, ograniczone zostały $\mathrm{w}$ zasadzie do niezbędnych $\mathrm{w}$ danym momencie ${ }^{33}$. W połowie lat 80., na łamach prasy, często zaczęto wspominać o budowie nowego budynku przeznaczonego dla Filmoteki, w którym mogłyby znaleźć się i magazyny,

33 H. Tronowicz, dz. cyt. 
i laboratoria, a także pomieszczenia administracyjne, które dałyby pełną swobodę $\mathrm{w}$ prowadzeniu działalności ${ }^{34}$.

W 1986 r. funkcję dyrektora Filmoteki Polskiej objął jej długoletni współpracownik Waldemar Piątek, który piastował to stanowisko przez ponad $20 \mathrm{lat}^{35}$. Za jego kadencji sporo się zmieniło, nie tylko w kwestii gromadzenia filmów, ich historii, ale także świadomości życia społecznego.

Rok po objęciu stanowiska dyrektora przez Waldemara Piątka, po raz trzeci minister ds. kultury zmienił nazwę instytucji - z Filmoteki Polskiej na Filmotekę Narodową ${ }^{36}$. W momencie tej zmiany częściowo przeobraził się jej status i zakres działania. Chodziło w tym raczej o nadanie Filmotece wyższej rangi. Należy jednak zaznaczyć, że Filmoteka Narodowa znalazła się podobnie jak Muzeum Narodowe, Zamek Królewski i zbiory wawelskie wśród kilku instytucji upowszechniania kultury o znaczeniu ogólnokrajowym. Dyrekcja Filmoteki zawsze dbała o to, by instytucja ta pełniła w dziedzinie kinematografii i historii filmu taką samą funkcję co Biblioteka Narodowa w dziedzinie książki. By stała się instytucją koordynującą prace związane z gromadzeniem, ochroną i opracowywaniem wszystkiego, co na taśmie filmowej zostało zapisane.Za dziedzictwo kulturowe uznawane jest zarejestrowanie ruchomego obrazu, niezależnie od nośnika. Zgodnie z belgradzką deklaracją UNESCO, każdy kraj ma obowiązek ochrony ruchomych obrazów w nienaruszonej formie. Zatem oryginalne stare taśmy filmowe traktuje się jako zabytki kultury XX w., starannie przechowuje się je i konserwuje. Według ówczesnego statutu Filmoteka powinna być przede wszystkim instytucją upowszechniania kultury, ochraniającą dorobek w dziedzinie filmu. W końcu latach 80. ówczesny dyrektor ubolewał nad brakiem lokalu, w którym można by realizować podstawowe zadania statutowe. Pokładał wielkie nadzieje w projekcie przeniesienia Filmoteki z ul. Puławskiej 61 do pasażu na Ursynowie ${ }^{37}$.

W owym czasie rozszerzono działalność naukowo-badawczą i oświatową. Zasób Filmoteki stał się doskonałym źródłem do badań, np. dla filmoznawców czy historyków kina. Ponownie zaczęto zwracać szczególną uwagę na udostępnianie zasobów filmowych, a także wszystkiego tego, co wiąże się z kinematografią. Traktowano to jako jedną z podstawowych form działalno-

${ }^{34}$ B. Drozdowski, M. Miodek, Ratować ocalate, rozmowa $z$ Waldemarem Piątkiem, „Film” 1988, nr 21.

35 A. Bukowiecki, dz. cyt.

36 O Filmotece Narodowej.

37 B. Drozdowski, M. Miodek, dz. cyt. 
ści filmoteki, czyli poza prezentacją filmów miało to być pokazywanie wszystkiego, co wiąże się z kinematografią. Ówcześnie były to np. liczne spotkania, konferencje czy publikacje. Filmoteka została powołana do ochrony dziedzictwa kulturalnego w dziedzinie filmu polskiego, ale i nie tylko. Gromadzone, przechowywane, upowszechniane i opracowywane są tutaj filmy istotne z punktu widzenia sztuki filmowej ${ }^{38}$.

W latach 90. szef Komitetu Kinematografii Waldemar Dąbrowski, który notabene przez lata był związany z Filmoteką, wykreślił placówkę z puli narodowych instytucji, pozostawiając jednak jej niezmienioną nazwę i przypisał ją do rejestru placówek określanych mianem „kulturalnych”, takich jak domy kultury ${ }^{39}$. Tym samym instytucja o charakterze centralnym i znaczeniu międzynarodowym, o wyjątkowo bogatej tradycji gromadzenia filmów, straciła swoją dotychczasową pozycję. Odbiło się to przede wszystkim na finansowaniu projektów Filmoteki, począwszy od zabiegów konserwatorsko-restauratorskich, po wzbogacanie zasobu, czyli zakupu nowych, przede wszystkim zagranicznych dzieł sztuki filmowej. Wszystko to zbiegło się razem z informacją o nieudanym przedsięwzięciu budowy centrum filmowego w Warszawie, w którym pokładano wielkie nadzieje. Do lat 90. siedziba Filmoteki pozostała bez zmian przy ul. Puławskiej w Warszawie. Co więcej, wszystkie pomieszczenia, zarówno głównej siedziby, jak i magazynów przy ul. Chełmińskiej i Wałbrzyskiej, były przez Filmotekę wynajmowane, przy czym jak na tamte czasy tylko ten przy ul. Chełmińskiej spełniał prawie wszystkie wymogi przechowywania materiałów audiowizualnych. Wątpliwości mogły budzić warunki przechowywania filmów barwnych, gdyż nie były one doskonałe. W owym czasie, z powodu braku pomieszczeń do przechowywania, część zbiorów umieszczono w wynajętych piwnicach domów mieszkalnych, gdyż wynajmowany w Pyrach magazyn uległ zawaleniu. Plakaty się tam znajdujące umieszczono wówczas w szufladach, jedna na drugiej, zatem dostęp do zbiorów był również ograniczony. Początek lat 90. nie był przychylny działalności instytucji. Doszły do tego duże problemy finansowe, które ukróciły działalność konserwatorską. Brak warunków przechowywania doprowadził do zagrzybienia części zasobu, ale z procesu odgrzybiania, musiano zrezygnować z powodów finansowych. $Z$ tego samego tytułu od stycznia 1990 r. przestał

${ }^{38}$ C. Prasek, Nie tylko w Iluzjonie, rozmowa z Waldemarem Piątkiem, „Przyjaźń” 1987, nr 18.

39 J. Kobus, Zagłada Filmoteki, „Sztandar Młodych” 1995, nr 70. 
ukazywać się kwartalnik „Iluzjon” oraz zmniejszyła się do minimum działalność wydawnicza książek o tematyce filmowej. Pomimo tych wszystkich kłopotów Filmoteka nie zaprzestała swojej działalności ${ }^{40}$.

Kolejna dekada nie była również przychylna dla Filmoteki Narodowej. Już rozbudowane działania, które nie ograniczały się tylko do gromadzenia, opracowywania i konserwowania zbiorów, zostały jeszcze poszerzona o działalność wydawniczą, naukowo-badawczą oraz za pośrednictwem kina Iluzjon, wszelkich konferencji i warsztatów o szeroko pojętą działalność oświatową, mającą na celu krzewienie kultury filmowej. W połowie lat 90. nastąpił kryzys, którego nikt do tej pory nie przewidział.

W 1995 r. Filmoteka Narodowa spotkała się z zarzutem o tzw. piractwo kinowe. Aby zrozumieć, skąd w ogóle wziął się ten problem, trzeba przytoczyć sytuację na rynku dystrybucyjnym w Polsce sprzed lat. Jedyny istniejący wówczas dystrybutor kupował filmy na zasadzie licencji udzielanych przez dystrybutorów zachodnich na określony czas. Umowy te w większości zawierzały klauzulę o konieczności zniszczenia materiałów po eksploatacji filmu. Z przyczyn oczywistych dla polskiej kultury i historii filmu, badań nad nim, klauzula ta była przez Filmotekę naruszana. Po wprowadzeniu regulacji prawnych dotyczących dystrybucji w naszym kraju i poza nim w tej kwestii nie podjęto stosownej decyzji, która umożliwiałaby dalsze gromadzenie, a przede wszystkim udostępnianie zbiorów. Nie zostało to jasno ujęte w polskich przepisach prawnych, które mogłyby zapewnić nieprzerwalną działalność instytucji. O „piractwo” posądziło Filmotekę stowarzyszenie siedmiu największych dystrybutorów amerykańskich. Jak się okazuje, doszło w tym czasie do nieporozumienia, gdyż swoje zasoby Filmoteka udostępniała, owszem, ale na potrzeby badawcze, naukowe, krzewiące kulturę i sztukę. Co prawda, przy Filmotece Narodowej działało kino Iluzjon, ale jego działalność określał statut Międzynarodowej Federacji Archiwów Filmowych: każde archiwum może prezentować swoje zbiory pod warunkiem, że pokazy nie przynoszą dochodu, są pojedyncze i ujęte w cykle dydaktyczno-historyczne ${ }^{41}$. Niemniej jednak na czas wyjaśnienia sprawy, pierwszy raz od 1959 r., zawieszono działalność kina. Pomimo całej tej nieprzyjemnej sytuacji Filmoteka Narodowa pozostała sama z tym problemem, gdyż żadne ówczesne władze nie zajęły się w odpowiedni sposób wyjaśnieniem tej sprawy.

40 W nastroju minorowym, 35 lat Filmoteki Narodowej, „Film” 1990, nr 17.

41 J. Słodowski, Skąd ten problem?, „Film” 1995, nr 9. 
W dobrym kierunku sprawy Filmoteki Narodowej zaczęły iść w 1996 r., po wejściu w życie ustawy o obowiązkowych egzemplarzach bibliotecznych, w myśl której Filmoteka miałaby otrzymać bezpłatnie kopię każdego filmu kinowego i telewizyjnego, na podobnych zasadach, co Biblioteka Narodowa. Realizacja tej ustawy pozwoliłaby utrzymać placówce status narodowej instytucji o charakterze centralnym ${ }^{42}$. W myśl ustawy Filmotece Narodowej w Warszawie przekazuje się po jednym egzemplarzu kopii filmu kinowego i telewizyjnego, obowiązkiem tym zostaje obciążony producent filmowy, co więcej, ma on przekazać swoje dzieło w najwyższym standardzie edytorskim (w rozumieniu technicznym) $)^{43}$.

Po niekorzystnych dla działalności Filmoteki przejściach z początku lat 90. wprowadzenie egzemplarza obowiązkowego stanowiło przejście ku lepszym czasom, które nastąpiły już pod koniec tej dekady. W 1999 r. ówczesny Przewodniczący Komitetu Kinematografii podjął decyzję o przejęciu przez Filmotekę Narodową zbiorów materiałów filmowych do polskich filmów fabularnych od Likwidatora Łódzkiego Centrum Filmowego. Były to w zasadniczej mierze taśmy optyczne i magnetyczne. Postanowiono, że cenne zbiory, liczące ponad 50 tysięcy pudeł, zostaną tymczasowo ulokowane w budynku byłego Wydziału Obróbki Taśmy Łódzkiego Centrum Filmowego, który został przez Likwidatora wydzierżawiony Filmotece od 22 października 1999 r. na okres 10 lat. Budynek za sprawą starań Filmoteki przystosowano na potrzeby archiwum filmowego. Zarządzeniem dy rektora Waldemara Piątka 1 czerwca 2000 r. został formalnie utworzony Oddział Filmoteki Narodowej w Łodzi. Do magazynów nowo powołanej jednostki trafiła całość zbiorów filmowych łódzkiej filmówki. Stan posiadania Oddziału Filmoteki w Łodzi systematycznie powiększał się w latach następnych. W latach 2002 i 2003 do Oddziału przekazane zostały zasoby filmowe, ikonograficzne oraz dokumentacja produkcyjna Studia Filmowego „Se - ma - for”, które zostało ostatecznie zlikwidowane w $2004 \mathrm{r}^{44}$

W chwili obecnej Filmoteka Narodowa w Warszawie jest państwową instytucją kultury, której przedmiotem działania jest ochrona narodowego dziedzictwa kulturalnego w dziedzinie kinematografii oraz upowszechnianie

42 A. Wyżyński, Polska droga do narodowej filmoteki, „Kino” 2005, nr 3.

43 Dz.U. 1996, nr 152, poz. 722.

44 T. Wijata, Archiwum Filmowe 3 Eąowa Oddziat Łódzki, http://www.fn.org.pl/ page/index.php?str=313 [dostęp: 28 XI 2014 r.] 
kultury filmowej. Działalność Filmoteki opiera się na trzech filarach: archiwizacji, informacji i edukacji ${ }^{45}$.

Placówka działa na podstawie ustawy z dnia 25 października 1991 r. o organizowaniu i prowadzeniu działalności kulturalnej ${ }^{46}$, ustawy o kinematografii $^{47}$ oraz statutu nadanego przez Ministra Kultury i Dziedzictwa Narodowego zarządzeniem z dnia 29 kwietnia 2008 r. $^{48}$

Filmoteka Narodowa, jako instytucja państwowa, posiada osobowość prawą i podlega bezpośrednio Ministrowi Kultury i Dziedzictwa Narodowego. Siedzibą niezmiennie od lat pozostaje miasto stołeczne Warszawa, a terenem działania obejmuje obszar całej Rzeczypospolitej Polskiej ${ }^{49}$. Siedziba placówki, mimo wielu starań, przez lata również nie zmieniła się, dalej znajduje się przy ul. Puławskiej $61 \mathrm{w}$ Warszawie.

Filmoteka Narodowa oprócz filmów gromadzi i archiwizuje dokumentację dotyczącą ich produkcji i rozpowszechniania, a także zbiory biblioteczne oraz eksponaty dotyczące historii filmu i kinematografiii ${ }^{50}$. Całość tych działań zawarta jest w filarze związanym z archiwizacją. Do podstawowych zadań instytucji w zakresie edukacji i informacji należy także szeroko pojęta działalność kulturalno-oświatowa i działalność wydawnicza. Pierwsza z nich polega na upowszechnianiu kultury filmowej, w tym udostępnianiu zasobów sztuki filmowej, ale nie tylko. Będą się w tym zawierały również projekty edukacyjne Filmoteki, takie jak wykłady dotyczące historii filmu. Druga działalność polega przede wszystkim na przygotowywaniu i wydawaniu opracowań dotyczących zadań statutowych placówki oraz materiałów filmowych i filmograficznych znajdujących się w jej zasobach w formie drukowanej lub multimedialnej ${ }^{51}$. Do wachlarza działań instytucji związanych z filarem edukacji i informacji należy również proces udostępniania dotyczący wspierania zadań, których celem jest upowszechnianie kultury filmowej w zakresie rozpowszechniania i promocji filmów o wysokich walorach artystycznych oraz

45 O Filmotece Narodowej.

46 Dz.U. 1987, Nr 22, poz. 127.

${ }^{47}$ Dz.U. 2005, Nr 132, poz. 1111.

${ }^{48}$ Zarządzenie nr 17 Ministra Kultury i Dziedzictwa Narodowego z dnia 29 kwietnia 2008 roku w sprawie nadania statutu Filmotece Narodowej, http://bip.mkidn.gov. pl/media/download_gallery/indexfbe6.pdf [dostęp: 28 XI 2014 r.

49 Tamże, $\$ 2$.

50 Tamże, $\$ 4$, pkt 3 i 5 .

51 Tamże, $\$ 4$, pkt 4 i 8. 
edukacyjnych w kinach studyjnych, w tym również działalność kin studyjnych podległych instytucji; co za tym idzie, współuczestniczenie w organizowaniu realizacji przedsięwzięć mających na celu upowszechnianie kultury filmowej, w tym imprez z tym związanych oraz edukacji filmowej prowadzonej właśnie w tychże kinach ${ }^{52}$. Przy całym procesie gromadzenia i udostępniania filmów naturalne wydaje się prowadzenie katalogu dzieł filmowych.

Od lat jednym ze stałych elementów działalności Filmoteki jest współpraca z krajowymi i zagranicznymi ośrodkami, wspierającymi działalność archiwów filmowych oraz działającymi na rzecz upowszechniania kinematografii i rozwijania kultury filmowej ${ }^{53}$. Ponadto do zadań instytucji należy produkcja filmów o tematyce związanej z przedmiotem działania Filmoteki oraz współudział w produkcjach filmowych w oparciu o zasoby Filmoteki Narodowej z zachowaniem praw autorskich i pokrewnych ${ }^{54}$.

Bibliografia:

Beylin Stefania, Filmoteka Polska - Muzeum Sztuki Filmowej, „Stolica” 1980, nr 22.

Białous Urszula, Kiedy Chaplin ptacze, „Polityka” 1980, nr 21.

Bukowiecki Andrzej, 55 lat Archiwum Filmowego, Jubileusz Filmoteki Narodowej, „Magazyn Filmowy" 2010, nr 13.

Cegiełkówna Iwona, Takie kino - rozmowa z Grażyna Grabowska, kierownikiem programowym Iluzjonu, „Reżyser” 2000, nr 3.

Drozdowski Bogumił, Miodek Mariusz, Ratować ocalate, rozmowa z Waldemarem Piątkiem, „Film” 1988, nr 21.

Kobus Justyna, Zagtada Filmoteki, „Sztandar Młodych” 1995, nr 70.

Ledochowski Aleksander, Biedni bogacze, „Film” 1985, nr 16.

Michałek Bolesław, Duch filmoteczny, „Kino” 1980, nr 6.

Modrzejewska Ewa, Taśmy prawdy, „Film” 2005, nr 3.

Niedźwiedzka Magdalena, Historia gromadzenia filmów w Polsce, „Archiwista Polski” 2014, nr 3.

Niezabitowska Małgorzata, Święty negatyw, „Kultura” 1975, nr 32.

Notatka, „Kino” 1985, nr 1.

52 Tamże, $\$ 4$, pkt 9 i 10.

53 Tamże, $\$ 4$, pkt 7 .

54 Tamże, $\$ 4$, pkt 11 . 
Nowicki Romuald, Międzynarodowy Kongres archiwów Filmowych w Warszawie, „Archeion" 1956, t. 26.

O Filmotece Narodowej, http://www.fn.org.pl/page/index.php?str=669 [dostęp: 28 XI 20104 r.]

Piątek Waldemar, 30 lat Filmoteki Polskiej, „Filmowy Serwis Prasowy” 1985, nr 11-12.

Pożar w archiwum, „Film” 1967, nr 42.

Prasek Cezary, Nie tylko w Iluzjonie, rozmowa z Waldemarem Piątkiem, „Przyjaźñ” 1987, nr 18.

Robótka Halina, Metodyka archiwalna. Opracowanie dokumentacji geodezyjno-kartograficznej, technicznej, audiowizualnej (fotografie, filmy, nagrania), Toruń 1988.

Słodowski Jan, Skąd ten problem?, „Film” 1995, nr 9.

Tronowicz Henryk, Postannictwo i budżet, „Kino” 1985 nr 2.

W nastroju minorowym, 35 lat Filmoteki Narodowej, „Film” 1990, nr 17.

Wijata Tadeusz, Archiwum Filmowe 3 Eąkowa Oddziat Eódzki, http://www.fn.org.pl/ page/index.php?str=313 [dostęp: 28 XI 2014 r.]

Zwaniecki Andrzej, Notatka z okazji jubileuszu, „Tygodnik Kulturalny” 1980, nr 26.

\section{Summary}

An Outline History of Filmoteka Narodowa (the National Film Archive)

The article shows an outline history of the oldest Polish institution collecting films. Filmoteka Narodowa started its activity in the 1950. and since then it is the only institution in Poland having such a wide holdings of films, especially feature films. The history of this institution shows, in some part, also the history of Polish cinematography. The collection of films is our national cultural heritage. The article describes the history of the institution, changes of its character; these are a reflection of changes in Polish cinematography that turned from a national company into one of the most commercial and lucrative branches of industry. A scope of operations of Filmoteka Narodowa in Warsaw, did not change diametrically since its funding. It is still a central institution, collecting and providing access to films, especially, but also film documentation, ephemerides connected with cinematography and photographs concerning history of Polish cinema. 
